\title{
Prevalence of Parasitic Diseases of Indian Major Carps in Selected Districts of West Bengal, India
}

\author{
G. Vijaysundardeva ${ }^{1,2} *$, Gadadhar Dash ${ }^{2}$, Kurva Raghu Ramudu ${ }^{3}$, \\ T.J. Abraham ${ }^{2}$ and K.U. Shyam ${ }^{1}$
}

${ }^{1}$ Aquatic Environment and Health Management Division, ICAR-Central Institute of Fisheries Education, Mumbai-61, India

${ }^{2}$ Department of Aquatic Animal Health, Faculty of Fisheries, West Bengal University of Animal and Fishery Science, Kolkata-37, India

${ }^{3}$ Karwar Regional Research Center, ICAR-Central Marine Fisheries Research Institute, Karwar, India

*Corresponding author

\section{A B S T R A C T}

\section{Keywords}

IMC, Parasite,

Prevalence,

Seasonal

\section{Article Info}

Accepted: 20 May 2018

Available Online:

10 June 2018
The present work was conducted to isolate and identify different parasites from Indian Major Carps. During the study period the severity of infection and Parasitic Frequency Index (PFI, \%) were also estimated in terms of month and seasons of fishes. For the investigative purpose different districts of West Bengal were selected considering the potential of fishery resources. For investigative purpose samples were collected from different districts namely Garia, Bamanghata, of South 24 Parganas District, Ulluberia of Howrah District, Memari of Burdwan district for considering the potential of fishery resources. Approximately 360 fishes were observed during the entire period of 12 months from April 2014 to March 2015. The parasite infested fishes were found to suffer mainly from respiratory manifestations, blackness of the skin and mortalities. The parasitic infestations were found to be the major problem and the most prevalent disease causative agents among cultured fish spp. Most of the parasites were collected from gills and body surfaces of the fishes. The isolated parasites were Myxobolus sp., Trichodina sp., Dactylogyrus sp., Lernea sp., Vorticella sp., Chilodenella sp., Argulus sp. and Ergasilus $s p$. During the study period, among these parasites Myxobolus $s p$. showed the highest severity and prevalence (PFI, 66.66\%) in rainy season. Remaining all parasites were found throughout the year and adult fishes were found to be more infested with these parasites compare to fingerlings.

\section{Introduction}

India remains very much concerned with the development of methods for increasing aquaculture production levels. Intensification of carp culture has no doubt helped in achieving this goal to greater extent, however, it has also propagated artificial stress to 
overcrowding, nutrients and metabolites accumulation, dissolved oxygen and other water quality problems. All such potential stressors have magnified the risk of outbreak of diseases and thus an integrated health management approach is needed involving eradication of pathogenic organisms, decreasing host susceptibility and correction of impaired environmental conditions, etc. Though the country possesses a large number of potential cultivable carp species, it is only the three Indian Major Carps viz., Catla (Catla catla), Rohu (Labeo rohita) and Mrigal (Cirrhinus mrigala). Production comes from over 2.25 million ha of tanks or ponds, 1.3 million ha of oxbow lakes, 3 million ha of reservoirs and 1.2 million ha of coastal brackish water area (Ayyappan, 2007).

The majority of freshwater fishes carry heavy infestation of parasites. The parasitic infestation is greatly influenced by the season, which basically interferes with the ecology and physiology of the fish. They are mainly grouped as protozoans, helminths and crustacean parasites. Therefore proper health management procedures should be followed with appropriate control measures to boost up aquaculture production. West Bengal being a 'rice-fish society', the State is highly significant historically, geographically and strategically since long past.

The state is situated with $21^{\circ} 38 \mathrm{~N}$ to $27^{\circ} 10 \mathrm{~N}$ and $85^{\circ} 38 \mathrm{E}$ with a geographical coverage area of $87,853 \mathrm{sq} \mathrm{km}$. It is endowed with remarkable variations of physiographic resources from the sea to snow having elevation $5 \mathrm{~m}$. in the south to $3658 \mathrm{~m}$ from main sea level in the north. The State has 37\% of pond resources in India of which $70 \%$ are utilized for fish culture producing 1 to 3 million tonnes of freshwater fin- fish per year. Of the total 2.76 lakh hectares of impounded water area, about $70 \%$ to $79 \%$ is presently under fish culture.
The state of West Bengal has always attracted attention for being the highest producer of freshwater table fish and fish seed in the country together with the unique distinction of having the maximum water area under traditional shrimp farming. Disease is one of the major constraints to intensification of aquaculture and may eventually become a limiting factor to the economic success of the industry. So the objectives of the present study were to isolate and identify different parasites from IMC and to find out the Parasitic Frequency Index (PFI, \%) in terms of months and seasons from selected districts of West Bengal.

\section{Materials and Methods}

The present study on the prevalence of parasitic infestation in freshwater carps was carried out for a period of 12 months between April 2014 to March 2015. The fish samples were collected from Garia, Bamanghata, of South 24 Parganas District, Ulluberia of Howrah District, Memari of Burdwan District West Bengal, India. The locations were selected in such a way that these units at different locations represent the concerned district. The samples were collected on a regular basis once in every month. In each sampling about 30 fishes comprising 15 of each Catla catla, Labeo rohita, Cirrhinus mrigala were collected in live condition. The fishes were brought to the laboratory in live condition with water filled buckets and the total length, body weight of fishes were taken.

The gills were examined for the presence of different parasites. The methods for collection and preservation of the samples for parasitic examination were followed as described by Soota (1980). The date and site of collection were recorded and the fishes were examined for parasites within 24 hours. External symptoms and health conditions of each specimen were recorded. The gills were 
removed with least damage and placed on separate petri-dishes containing physiological saline water and examined. Each of the four pairs of gills of was examined separately. The gills were checked thoroughly for any parasites. Phenotypic characterization of all protozoans, monogenians, digeneans, and parasites were studied as described by Soulsby (1982). Photomicrographs were taken using a Motic BA400 phase contrast microscope with in-built digital camera.

\section{Determination of Parasitic Frequency Index (PFI)}

The Parasitic Frequency Index (PFI) was calculated by taking the percentage of the number of hosts infected by an individual parasite species against the total number of hosts examined in a particular area under investigation.

Prevalence $(\%)=($ Total number of infected fishes/Total number fish hosts examined)x100

The frequency index were further classified into rare $(0.1-9.9 \%)$, occasional (10- $29.9 \%)$, common $(30-69.9 \%)$ and abundant (70$100 \%$ ) as per Srivastava (1980).

\section{Determination of severity of infection/ infestation}

In order to assigning numerical qualitative value to severity grade of infections surface infestation and disease syndrome severity, the generalize scheme by Lightner (1993) was followed (Table 1).

\section{Statistical analysis}

Two way ANOVA was done to determine the siginificance of differences in Parasitic Frequency Index (PFI) of parasites among different seasons as well as different months. Duncan's Test at $1 \%$ and $5 \%$ were done to know the significance of differences at microlevel.

\section{Results and Discussion}

\section{Monthly prevalence of different parasites in Catla catla}

Monthly distribution of parasites in Catla catla is given in the following table (Table 2). Occurrence of parasitic fauna such as Myxobolus sp., Thelohanellus sp., Trichodina sp., Dactylogyrus sp., Argulus sp., Lernaea sp., Ergasilus sp., Chilodonella sp., were reported from Catla catla in our present study. Parasitic Frequency Index (PFI) of Myxobolus $s p$. (Fig. 1) were found highest in September (PFI, 66.66\%) stated as "common" and lowest prevalence was found in February month (PFI, $20 \%$ ) stated as "occasional". These results supported by Das et al., (1989), Seenappa and Manohar (1980), Narasimhamurti and Kalavati (1984) and Basu and Haldar (2003) who have recorded high prevalence of myxozoan parasites during August to January when the ambient temperature was $25^{\circ} \mathrm{C}$ and lowest prevalence in the month of February (20\%). PFI (\%) values of Thelohanellus sp. Suggesting that the November month found to be the occasional condition and the rare condition was found to be in May, August, September, February and March, but Kaur et al., (2012) reported $100 \%$ prevalence of infection in the month of May against complete $0 \%$ prevalence in the present study and the probable reason may be the difference in geographical area. The earlier studies reported that the Thelohanellus sp., highest prevalence found in February (PFI, 31.66\%) lowest in August (PFI, 11.66\%). This could be due to high stocking density, water depth, temperature along with other physiochemical parameters and management practices maintained in culture systems these results corroborated with results of Banu and Khan, (2004). 
The prevalence graph showed the peaks at the month of September and December (PFI, $28.33 \%$ ) for Dactylogyrus sp. and lowest occurrence was in April. (Fig. 2).A rare condition was observed with PFI of $5.0 \%$ for Argulus sp., in December and February and which was not recorded in rest of the months. Lernaea $s p$. found rarely and occasionally (PFI, $13.33 \%$ and $3.33 \%$ respectively) in the month of October and November, rest of the months not recorded. Ergasillus $s p$. was found rarely in the month of December and January (PFI, 8.69\% and 4.76\%), Chilodonella sp. (PFI, 3.33\%)

\section{Occurrence of parasites in different seasons in Catlacatla}

The seasonal influence on parasites has been described by several researchers like Bhuiyan et al. (2007), Banu et al. (1993), Chandra et al. (1997) who worked on seasonal variations. The total study period was divided into four seasons; i.e. summer (April - June); rainy season (July-September) or Monsoon Winter (October- January) and spring (FebruaryMarch).

The infestation cycle of Myxobolus sp. were interestingly shown a seasonal-wise constant increase from summer to winter with highest during monsoon (PFI, 43.33\%) and lowest during spring (PFI, 30.83\%) (Table-3, Fig. $6)$. The significant fluctuation in the prevalence of parasites are due to the seasonal interference with the ecology and physiology of the fish (Ahmed et al. 1991; Wisheiwski, 1958). Polanski(1961) reported that the main factors determining the variety of parasitic fauna as well as the intensity and incidence of infection can be the diet and lifespan of the host, the mobility of the host throughout its life including the variety of habitats it encounters, its population density and the size attained, large hosts provide more habitats suitable for parasites than do small ones.
Thelohanellus sp. increased its occurrence from summer to monsoon season with an occasional peak (PFI, 14.44\%) and a rare case in Spring (PFI,10\%). The probable reason for the availability of this parasite only in intestine may be due to the feeding habit of the hosts or due to the organ specific nature of the parasites.

All seasonal abundance was observed for Trichodina $s p$. during the study period. A gradual decrease in the infection intensity was observed from summer (PFI, 12.22\%) to spring (PFI, 3.33\%). Interlamellar forms of protozoan parasites (Trichodina sp.) may cause some necrosis of gills and occasional death. Gillmyxoboliasis, has caused heavy losses in Indian major carps which was corroborated by Hossain et al., (1994a).

Dactylogyrus $s p$ were found in all seasons and highest in Monsoon (PFI,22.77\%) and lowest in spring (PFI, 2.91\%) which was supported by Ghosh et al. (1987) who found the highest infestation of Dactylogyrus sp. in Catlacatla. Hoole et al., (2001). In the present study monogeneans were observed mainly in the gills and skin of the host cat fishes as they are ectoparasitic in nature. Similar results given by Wooten (1974), he observed Dactylogyrus $s p$. aggregating on certain areas of the gills and skin of the host.

The results attained by him suggested that the site of attachment of parasite was influenced, atleast in part, by the direction and force of the respiratory current over the gills. Most parasites select a site where they are not subjected to full force of water current. Ghosh et al. (1987) observed dactylogyrids in gill filaments of the Catla catla. A microcotylid Bivagina tai was found on the gills of cultured red sea bream Pagrus major. These parasites draw good nourishment from the gills very easily as reported by Ogawa (1988). 
Argulus sp. were found mainly in the winter (PFI, $0.41 \%$ ) stated as rare and not found in the rest of the seasons. Lernea sp. (PFI, $0.55 \%$ ), Ergasillus sp. (PFI, $0.55 \%$ and $0.41 \%$ ) were rarely found in monsoon and winter season. During winter and spring, when the carps loose their appetite results stress condition and get affected by different diseases at that time, Catla catla are seen to be attacked by the Argulus sp. which similar with results of Ray (1993) and this also corroborated with work of other authors (Shimura, 1983a,b; Shafir and Van AS, 1986; Mikheev et al., 2001 and Samir, 2007), who reported on Argulus sp. in IMC, where as many authors revealed that the incidence of argulosis were found throughout the year (Mohan et al., 1986 and Landsberg, 1989). However, some other scientist opined the highest incidence of argulosis in summer contrary to the present study suggesting a positively related stress condition due to oxygen depletion (Singhal et al., 1986).

\section{Prevalence of different parasites in Rohu (Labeo rohita)}

The major parasites fauna recorded in Rohu during the current study period are Myxobouls sp., Thelohanellus sp., Trichodina sp., Dactylogyrus sp., Argulus and Ergasilus sp. (Table 4, Fig. 1, 3). The PFI values of these parasites shows its abundance of occurrence in the host and the common, occasional and rare status also given based on this PFI values. Infection with Myxobolus sp., was regarded as the common condition in the rohu as the PFI values $(66.66 \%)$ reaches its maximum in the month of September. On comparison with the occurrence of Thelohanellus sp., was recorded lowest in this month (PFI 8.33\%). Which was either present throughout the year except in April. Occasional abundance was observed in the month of February, in case of Myxobolus sp. (PFI 16.66\%) whereas Thelohanellus sp., increased their abundance in the following months and reaches its maximum at March and June (PFI 36.66\%). These observations were concomitant with the findings of Bhuiyan et al., 2007, Akhter et al, (1997), Banu etal, (1993), Chandra et al, (1997) and Hossain et al,(1994a,b) in Rohu.

PFI (\%) of Trichodina sp. varied from $3.33 \%$ to $15 \%$ throughout the year, highest in the month of June (PFI, 15\%) stated as occasional and lowest in the month of February (PFI, $3.33 \%$ ) stated as rare. These were found occasionally in November, December and January and also found rare condition in the months of April, May, July, August, October and February. Majumder (2011) who studies of Trichodina sp. on exotic carps, which were also corroborated the results of present findings. PFI of Dactylogyrus sp. were highest in the month of November (PFI, 38.33\%) which were stated as ,occasionale condition. The results of the present study corroborates with that of Ghosh et al. (1987), Ogawa (1988) and Kim et al. (2001). Ogawa (1988) reported higher prevalence of Bivagina tai (a microcotylid, monogenean) in October to January (winter months).Ghosh etal.(1987)alsoobservedhighestinfestationof $D$ actylogyrussp.inIndianMajorCarp (Labeo rohita) during winter (December and February) which was similar to this study.

Argulus sp. were only found during November, December and January (PFI, 5\%, $5 \%$, and $20 \%$ respectively) which considered as occasional and rest of the months it was not recorded and the present results were supported with the findings of Nandi et al., 1991; Radheshyam et al., (1993); Das and Das (1995) Shella et al. (2002) and Samir (2007). Lernaea sp., found occasionally (PFI, 18.33 and $10 \%$ respectively) in the month of November and December and found rare in the month of February and March (PFI, $8.33 \%$ ) and rest of the months these were not recorded. Ergasillus sp. (PFI, 5\%) were found rarely in the months of December and January. 
Bauer et al., 1969 reported that low temperatures which may be more congineal for reproduction of crustaceans and some trichodinids and this supports the present findings. The probable reason for the availability of more developmental stages in winter may be due to the delaying of developmental process at low temperature as suggested by Schaperclaus, 1954, at a temperature of $15-17^{\circ} \mathrm{C}$; Present results strongly supported by Bhuiyan et al. (2007), who opinied about monthly fluctuation in prevalence, mean intensity and abundance of parasites in L. rohita. The maximum prevalence $(100 \%)$ was recorded in November, December and January. IMC fingerlings become more susceptible to pathogen because of their immature poor immune system (Anderson, 1974), this strongly supports the present findings.

\section{Occurrence of parasites in different seasons in Labeorohita}

The seasonal prevalence data of parasites on Rohu also was not distinct. In case of Myxobolus sp. all seasonal appearance was recorded. Rainy season abundance was reportedly common (PFI, 52.77\%)and lowest infections were in spring (PFI, 12.5\%) (Table 5, Fig. 5).These results are strongly supported with Bhuiyan et al., 2007, in L.rohita. Prevalence of Thelohanellus sp. were decreased from winter to spring (PFI, $18.75 \%$ to $16.66 \%$ ). These parasites occasionally found in summer (PFI, 11.11\%) and rainy (PFI, 23.8\%) and commonly found in spring season and winter (PFI, $16.66 \%$ and $18.75 \%$ ). This was probably due to the fact that decrease in water volume during the dry season caused nutritional imbalance resulting in less production of fish food organisms in one hand and on the other hand fall in water temperature and reduced the immune response in fish and made them more vulnerable to disease vectors. So present results supported by Akhter et al.
(1997), Banu et al. (1993), Chandra et al. (1997) and Hossain et al.(1994). Trichodina $s p$. occasionally found in monsoon and winter (PFI, $13.8 \%$ and $10.83 \%$ respectively), but rarely found in spring and summer (PFI, $1.56 \%$ and $5.55 \%$ ). This was attributed outbreak of disease due to the sudden seasonal fluctuations in the water quality during winter and monsoon season. Trichodina sp. were extensively isolated from gills of tilapia and catfishes (Derwa, 1995; Osman, 2001; Younis, 2004 and El-Shahat, 2004) which corroborated with the present findings. Hines and Spira $(1973,1974)$ reported the infection of the gills of fish by these protozoan parasites.

The experimental findings also supported the fact that the fish fingerlings become more susceptible to pathogen because of their immature immune system (Anderson, 1974). Kabata (1985) reported that shallow ponds and stagnant water favours the multiplicity of ciliate like Trichodina. In the year 1992 in Philippines Trichodina were reported as the most prevalent ectoparasite followed by Dactylogyrus (Lumanlan et al., 1992). The present study agreed with works of Subasinghe (1992), Sharif and Vijarungam (1986) who had reported these two parasites were the most common and caused mass mortality of fish during their study in the carp fish nursery operation system in Malaysia.

The documented prevalence of Dactylogyrus $s p$. highlighting that it reaches peak in spring (PFI, 20.8\%), which stated as, 'occasionale, low in summer (PFI, 10\%) stated as occasional condition. The results of this study are similar with that the results of Kollmann (1972), Paperna (1963a), Aydogdu and Altunel (2002), Mo (1992), Hoole et al. (2001) and Ghosh et al. (1987). Prevalence of Ergasillus sp. were found only in winter (PFI, $1.66 \%$ ) which was stated as, rare. Lernaea sp. were found rarely in rainy (PFI, $0.55 \%$ ) and the other seasons were not recorded. 
Development stages were also found rarely in monsoon season (PFI, 2.77\%). Idris and Amba (2001) showed that temperature fluctuations during monsoon season could have contributed to the infestation. In the present study Lernaeasp. were found rarely in the monsoon season (PFI, 0.55) and not found in rest of the seasons which is similar to the findings of the above author.

\section{Prevalence of different parasites in Cirrhinusmrigala}

Month-wise prevalence data of Myxobolus sp. also in accordance with the seasonal data as PFI were highest in November (PFI, 55\%) stated as common and lowest in the month of May (PFI, 16.66\%) stated as also occasional. The Thelohanellus sp highest in November (PFI, 41.66\%) stated as occasional and lowest in the month of May (PFI, 8.33\%) stated as rare (Table 6, Fig. 1, 4).

Present study was supported by the work of Farhaduzzaman et al., 2010, During his study period at Rajshahi, Bangladesh, the highest number of parasites reported in December month and lowest in February. Das et al. (1989), Seenappa and Manohar (1980), Narasimhamurti and Kalavati (1984), Basu and Haldar (2003) recorded high prevalence of myxozoan parasites during August to January when the ambient temperature was $25^{\circ} \mathrm{C}$. These findings were deviated from the work of Bhuiyan et al., 2007. The parasitic infestation is greatly influenced by the season, which basically interferes with ecology and physiology of the fish. As the water quality parameters fluctuate very quickly during winter and summer season, fish becomes affected with diseases in these seasons. During the breeding season of fish lesser number of parasites invade the host because of the presence of the oestrogen these were supported by Rahman and Jahan (2002).

The study experienced that Trichodina $s p$. were found highest in the month of December (PFI, 11.66\%) and rarely seen in the month of October and February (PFI, 3.33\%). It may due to high stocking density is being maintained during carp nursery operations, and this density induces bio-ecological stress to fry (Passion, 1984) and make the fry more susceptible to the infection (Sneisko, 1974). It is evident from the available literature that parasitic diseases caused significant damage in nursery systems of carp, catfish and shellfish of Srilanka (Subashinghe, 1992), Malaysia (Leong, 1992), Indonesia (Angka et al., 1982), Taiwan (Song et al., 1980) and India (Gopalkrishnan,1961).

Various physicochemical factors suchas water and atmospheric temperature, $\mathrm{pH}$, hardness of water, dissolved oxygen, biological oxygen demand (BOD) have strong impacts on fish health and their resistance to attack by the causative agents. Present study strongly supported by Welch, 1941; Snieszko 1974; Plumb et al. 1988; and Shresta (1990). Ichthyophthirius multifilis were found only in the month of December (PFI, 6.66\%) as rare, rest of the months were not observed.

Dactylogyrus sp. were commonly encountered with a peak in January (PFI 35\%) not found in March and occasional appearance with lowest in the month of May (PFI, 13.33\%) except in March. These results are concomitant with that the results of Kollmann 1972, Paperna 1963a, Aydogdu and Altunel, 2002, Mo 1992, Hoole et al. 2001 and Ghosh et al., 1987. 
Table.1 Assigning numerical qualitative value to severe grade of infestations/infections

\begin{tabular}{|c|c|}
\hline Severitygrade & Clinicalfindings \\
\hline 0 & $\begin{array}{l}\text { No signs of infection by pathogen, parasite. No lesions characteristicof } \\
\text { syndromepresent. }\end{array}$ \\
\hline 0.5 & $\begin{array}{l}\text { A very few scattered signs of infection by pathogen, parasite. } \\
\text { Nolesions characteristic of syndromepresent. }\end{array}$ \\
\hline 0.5 & $\begin{array}{l}\text { A very few scattered signs of infection by pathogen, parasite. } \\
\text { Nolesions characteristic of syndromepresent. }\end{array}$ \\
\hline 1.0 & $\begin{array}{l}\text { Pathogen, parasite but in numbers or amounts just abovediagnostic } \\
\text { procedure minimum detectionlimits. } \\
\text { Lesions characteristic of syndrome present, but "disease" } \\
\text { notsignificant. } \\
\text { Prognosisisforinsignificanteffect,exceptindevelopinginfectionsby }\end{array}$ \\
\hline 2.0 & $\begin{array}{l}\text { Low to moderate numbers of pathogen, parasite. Light to } \\
\text { moderatelesions characteristic of syndromepresent. } \\
\text { Prognosis is for possible production losses and/or slight increasesin } \\
\text { mortality if no treatment (if treatable)applied. }\end{array}$ \\
\hline 3.0 & $\begin{array}{l}\text { Moderate numbers of pathogen,parasite. } \\
\text { Moderate to severe lesions characteristic of } \\
\text { syndromepresent. Potentially lethal prognosis if no } \\
\text { treatment (if treatable)applied. }\end{array}$ \\
\hline
\end{tabular}




\section{Int.J.Curr.Microbiol.App.Sci (2018) 7(6): 2784-2805}

Table.2 Prevalence (PFI, \%) of different parasites in Catla catla from April 2014 to March2015

\begin{tabular}{|c|c|c|c|c|c|c|c|c|c|c|c|c|}
\hline \multirow[t]{2}{*}{ Parasites } & \multicolumn{12}{|c|}{ Monthly PFI (\%) of Catlacatla } \\
\hline & $\begin{array}{l}\text { A } \\
\mathrm{pr} \\
\text { il }\end{array}$ & May & June & July & $\begin{array}{l}\text { Aug } \\
\text { ust }\end{array}$ & $\begin{array}{l}\text { Septemb } \\
\text { er }\end{array}$ & $\begin{array}{l}\text { Octob } \\
\text { er }\end{array}$ & $\begin{array}{l}\text { Novemb } \\
\text { er }\end{array}$ & $\begin{array}{l}\text { Decemb } \\
\text { er }\end{array}$ & $\begin{array}{l}\text { Janu } \\
\text { ary2 } \\
015\end{array}$ & $\begin{array}{l}\text { Februa } \\
\text { ry }\end{array}$ & March \\
\hline Myxobolussp. & $46.66^{\mathrm{c}}$ & $25^{\mathrm{c}}$ & $35^{\mathrm{c}}$ & $56.66^{\mathrm{c}}$ & $50^{c}$ & $66.66^{\mathrm{c}}$ & $58.33^{\mathrm{c}}$ & $60^{c}$ & $58.3^{b}$ & $41.66^{\mathrm{c}}$ & $20^{\mathrm{b}}$ & $41.66^{\mathrm{c}}$ \\
\hline Thelohanellussp. & $23.33^{b}$ & 0 & $26.66^{\mathrm{b}}$ & $31.66^{\mathrm{b}}$ & $11.66^{\mathrm{b}}$ & 0 & 0 & $25^{b}$ & $15^{\mathrm{b}}$ & $25^{\mathrm{b}}$ & $31.66^{\mathrm{c}}$ & $15^{\mathrm{b}}$ \\
\hline Trichodinasp. & $11.66^{\mathrm{b}}$ & $3.33^{\mathrm{a}}$ & $5^{\mathrm{a}}$ & $18.33^{\mathrm{b}}$ & $3.33^{\mathrm{a}}$ & $3.33^{\mathrm{a}}$ & $3.33^{\mathrm{a}}$ & $20^{\mathrm{a}}$ & $11.66^{\mathrm{b}}$ & $5^{\mathrm{a}}$ & $3.33^{\mathrm{a}}$ & $3.33^{\mathrm{a}}$ \\
\hline Dactylogyrussp. & $3.33^{b}$ & $17^{\mathrm{b}}$ & $10^{b}$ & $21.66^{\mathrm{b}}$ & $20^{\mathrm{b}}$ & $28.33^{b}$ & $16.66^{\mathrm{b}}$ & $6.66^{\mathrm{a}}$ & $28.33^{\mathrm{b}}$ & $18.33^{\mathrm{b}}$ & $25^{\mathrm{b}}$ & $16.66^{\mathrm{b}}$ \\
\hline Argulussp. & 0 & 0 & 0 & 0 & 0 & 0 & 0 & 0 & $5^{\mathrm{a}}$ & 0 & $5^{\mathrm{a}}$ & 0 \\
\hline Lerneasp. & 0 & 0 & 0 & 0 & 0 & 0 & $13.33^{b}$ & $3.33^{\mathrm{a}}$ & $5^{a}$ & 0 & 0 & 0 \\
\hline Ergasilus sp. & 0 & 0 & 0 & 0 & 0 & 0 & 0 & 0 & $8.69^{\mathrm{a}}$ & $4.76^{\mathrm{a}}$ & 0 & 0 \\
\hline Chilodonellasp. & 0 & 0 & 0 & 0 & 0 & 0 & 0 & 0 & $3.33^{\mathrm{a}}$ & $11.66^{b}$ & 0 & 0 \\
\hline $\begin{array}{r}\text { Ichthyophthirius } \\
\text { multifilis }\end{array}$ & 0 & 0 & 0 & 0 & 0 & 0 & 0 & 0 & 0 & 0 & 0 & 0 \\
\hline
\end{tabular}




\section{Int.J.Curr.Microbiol.App.Sci (2018) 7(6): 2784-2805}

Table.3 Prevalence (PFI, \%) of parasites in Catla catla in different seasons from April 2014 to March, 2015

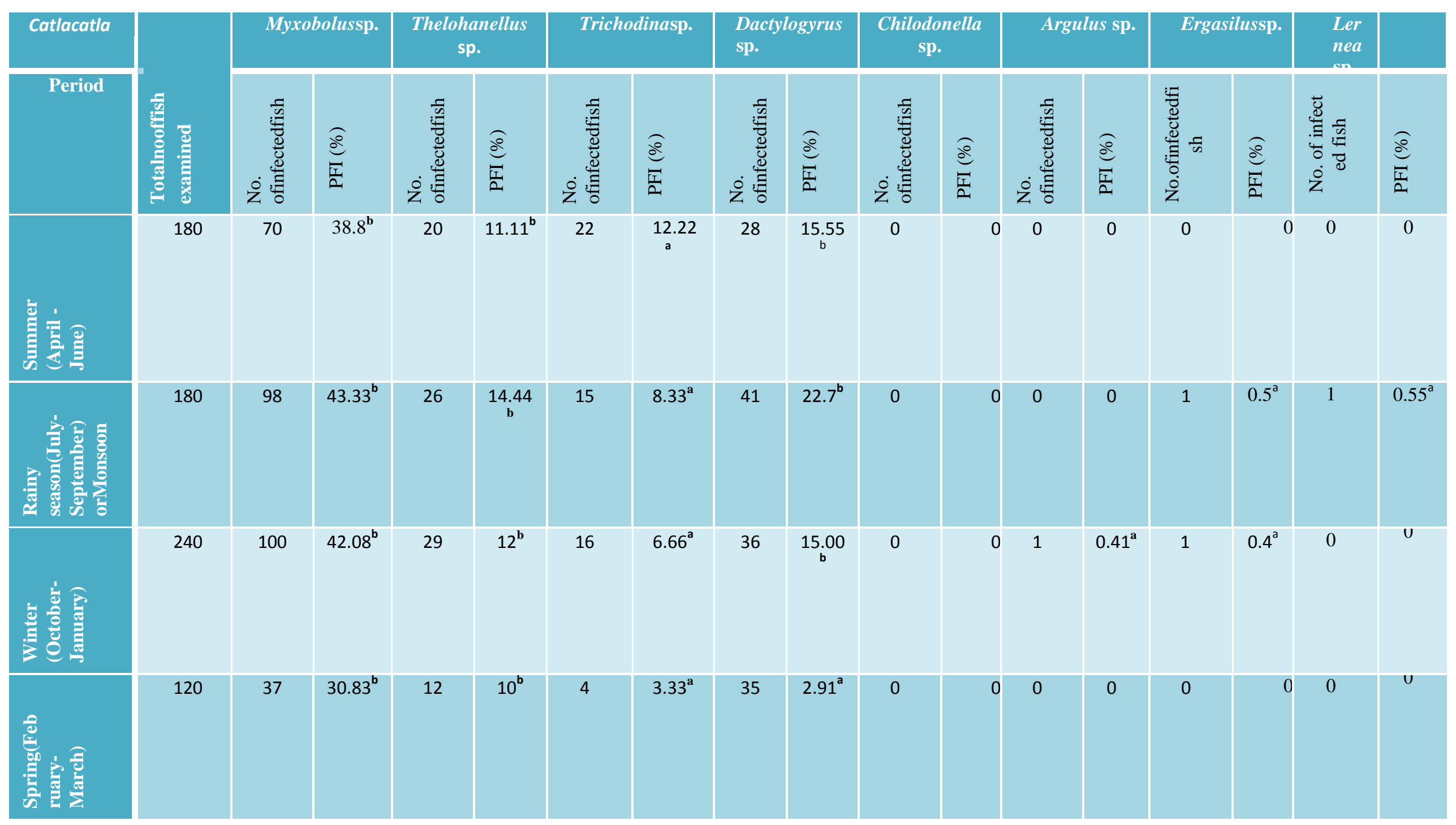

PFI=ParasiticFrequencyIndex(\%).a=rare(0.1-9.9\%); $\mathrm{b}=\mathrm{occasional}(10-29.9 \%) ; \mathrm{c}=\mathrm{common}(30-69.9 \%) ; \mathrm{d}=\mathrm{abundant}(70-100 \%)$. 
Table.4 Prevalence(PFI,\%)ofdifferentparasites inLabeo rohitafromApril2014 to March2015

\begin{tabular}{|c|c|c|c|c|c|c|c|c|c|c|c|c|}
\hline \multirow[t]{2}{*}{ Parasites } & \multicolumn{12}{|c|}{ Monthly PFI (\%) Labeorohita } \\
\hline & $\begin{array}{l}\text { April } \\
2014\end{array}$ & May & June & July & August & September & October & November & December & January & February & March \\
\hline Myxobolussp. & $50^{\mathrm{c}}$ & $33.33^{c}$ & $61.66^{c}$ & $56.66^{\mathrm{c}}$ & $40^{\mathrm{c}}$ & $66.66^{\mathrm{c}}$ & $56.66^{\mathrm{c}}$ & $58.33^{\mathrm{c}}$ & $33.33^{c}$ & $65^{\mathrm{c}}$ & $16.66^{\mathrm{b}}$ & $26.66^{\mathrm{b}}$ \\
\hline Thelohanellussp & 0 & $25^{\mathrm{b}}$ & $36.66^{c}$ & $11.66^{b}$ & $16.66^{b}$ & $8.33^{b}$ & $13.33^{b}$ & $16.66^{b}$ & $26.66^{b}$ & 0 & $25^{b}$ & $36.66^{c}$ \\
\hline Trichodinasp. & $6.66^{\mathrm{a}}$ & $6.66^{\mathrm{a}}$ & $15^{b}$ & $5^{\mathrm{a}}$ & $5^{\mathrm{a}}$ & 0 & $5^{\mathrm{a}}$ & $10^{\mathrm{b}}$ & $13.33^{b}$ & $10^{b}$ & $3.33^{\mathrm{a}}$ & $6.66^{\mathrm{a}}$ \\
\hline Dactylogyrussp & $25^{b}$ & $26.66^{b}$ & $25^{b}$ & $26.66^{b}$ & $18.33^{b}$ & $25^{b}$ & $21.66^{b}$ & $38.33^{\mathbf{b}}$ & $35^{b}$ & $28.33^{c}$ & $30^{c}$ & $20^{b}$ \\
\hline Argulussp. & 0 & 0 & 0 & 0 & 0 & 0 & 0 & $5^{\mathrm{a}}$ & 5 & $20^{\mathrm{a}}$ & 0 & 0 \\
\hline Ergasilus sp. & 0 & 0 & 0 & 0 & 0 & 0 & 0 & 0 & $6.66^{\mathrm{a}}$ & 0 & 0 & 0 \\
\hline Lerneasp. & 0 & 0 & 0 & 0 & 0 & 0 & 0 & $18.33^{b}$ & $10^{b}$ & 0 & $8.33^{\mathrm{a}}$ & $8.33^{\mathrm{a}}$ \\
\hline Developmental stage & 0 & 0 & 0 & 0 & 0 & 0 & $1.66^{\mathrm{a}}$ & 0 & 0 & 0 & 0 & 0 \\
\hline
\end{tabular}

PFI=Parasitic Frequency Index $(\%)$. a=rare $(0.1-9.9 \%) ; b=$ occasional $(10-29.9 \%) ; c=$ common $(30-69.9 \%)$; $=$ abundant $(70-100 \%)$

Table.5 Prevalence (PFI, \%) of parasites in Labeo rohita in different seasons from April 2014 to March2015

\begin{tabular}{|c|c|c|c|c|c|c|c|c|c|c|c|c|c|}
\hline \multirow{2}{*}{$\begin{array}{l}\text { Labeorohita } \\
\text { Period }\end{array}$} & \multirow{2}{*}{$\begin{array}{l}\text { Total } \\
\text { no. of } \\
\text { fish } \\
\text { exami } \\
\text { ned }\end{array}$} & \multicolumn{2}{|c|}{ Myxobolussp. } & \multicolumn{2}{|c|}{ Thelohanelluss } & \multicolumn{2}{|c|}{ Trichodinasp. } & \multicolumn{2}{|c|}{ Dactylogyrussp. } & \multicolumn{2}{|c|}{ Lernaeasp } & \multicolumn{2}{|c|}{ D.stages } \\
\hline & & 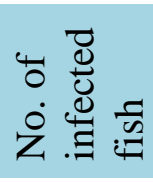 & 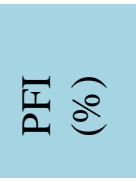 & 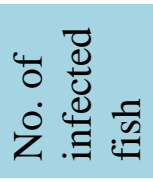 & $\overrightarrow{\frac{1}{2}} \overbrace{}^{0}$ & 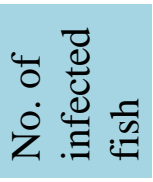 & $\frac{\pi}{2}$ & 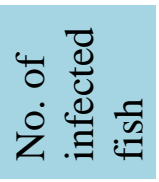 & $\sqrt{2} \underbrace{2}$ & 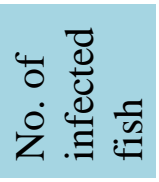 & $\overrightarrow{\frac{\pi}{2}}$ & 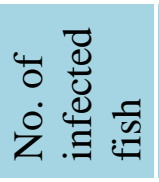 & $\frac{\pi}{2} \underbrace{2}$ \\
\hline $\begin{array}{l}\text { Summer (April - } \\
\text { June) }\end{array}$ & 180 & 65 & $36.11^{c}$ & 20 & $11.11^{b}$ & 10 & $5.55^{a}$ & 18 & $10^{b}$ & 0 & 0 & 0 & 0 \\
\hline $\begin{array}{l}\text { Rainy season (July- } \\
\text { September) or } \\
\text { Monsoon }\end{array}$ & 180 & 95 & $52.77^{c}$ & 43 & $23.8^{b}$ & 25 & $13.8^{b}$ & 26 & $14.4^{b}$ & $1^{a}$ & $0.55^{\mathrm{a}}$ & $5^{a}$ & $2.77^{\mathrm{a}}$ \\
\hline $\begin{array}{l}\text { Winter } \\
\text { (October- }\end{array}$ & 240 & 101 & $42.00^{b}$ & 45 & $18.75^{b}$ & 26 & $10.83^{b}$ & 32 & $13.33^{b}$ & 0 & 0 & 0 & 0 \\
\hline $\begin{array}{l}\text { Spring } \\
\text { (February- }\end{array}$ & 120 & 15 & $12.5^{b}$ & 20 & $16.66^{b}$ & 2 & $1.66^{\mathrm{a}}$ & 25 & $20.8^{b}$ & 0 & 0 & 0 & 0 \\
\hline
\end{tabular}

PFI=Parasitic Frequency Index $(\%)$. a=rare $(0.1-9.9 \%) ; b=$ occasional $(10-29.9 \%) ; c=$ common $(30-69.9 \%) ; d=a b u n d a n t(70-100 \%)$. 


\section{Int.J.Curr.Microbiol.App.Sci (2018) 7(6): 2784-2805}

Table.6 Prevalence (PFI, \%) of different parasites in Cirrhinus mrigala from April 2014 to March2015

\begin{tabular}{|c|c|c|c|c|c|c|c|c|c|c|c|c|}
\hline \multirow{2}{*}{ Parasites } & \multicolumn{12}{|c|}{ Monthly PFI (\%) of Cirrhinus mrigala } \\
\hline & $\begin{array}{l}\text { Apr } \\
\text { il }\end{array}$ & May & June & July & August & September & October & $\begin{array}{l}\text { Novembe } \\
\mathrm{r}\end{array}$ & December & $\begin{array}{l}\text { Janua } \\
\text { ry }\end{array}$ & February & $\begin{array}{l}\text { Marc } \\
\mathrm{h}\end{array}$ \\
\hline Myxobolussp. & $28.33^{\mathrm{b}}$ & $16.66^{\mathrm{b}}$ & $26.66^{\mathrm{b}}$ & $31.66^{\mathrm{c}}$ & $35^{\mathrm{c}}$ & $25^{\mathrm{c}}$ & $33.33^{c}$ & $55^{\mathrm{c}}$ & $33.33^{c}$ & $25^{\mathrm{b}}$ & $31.66^{\mathrm{c}}$ & $20^{\mathrm{b}}$ \\
\hline $\begin{array}{l}\text { Thelohanelluss } \\
\text { p. }\end{array}$ & $36.66^{\mathrm{c}}$ & $8.33^{\mathrm{a}}$ & $16.66^{\mathrm{b}}$ & $25^{\mathrm{b}}$ & $11.66^{\mathrm{b}}$ & 0 & $23.33^{b}$ & $41.66^{\mathrm{b}}$ & $10^{\mathrm{b}}$ & 0 & $25^{\mathrm{b}}$ & $20^{\mathrm{c}}$ \\
\hline Trichodinasp. & $5^{\mathrm{a}}$ & $6.66^{\mathrm{a}}$ & $10^{\mathrm{b}}$ & $5^{\mathrm{a}}$ & $5^{\mathrm{a}}$ & 0 & $3.33^{\mathrm{a}}$ & $8.33^{\mathrm{a}}$ & $11.66^{\mathrm{b}}$ & 0 & $3.33^{\mathrm{a}}$ & $5^{\mathrm{a}}$ \\
\hline Dactylogyrussp. & $25^{\mathrm{b}}$ & $13.33^{b}$ & $20^{b}$ & $16.66^{b}$ & $21.66^{c}$ & $28.33^{b}$ & $21.66^{b}$ & $23.33^{b}$ & $16.66^{b}$ & $35^{\mathrm{c}}$ & $25^{\mathrm{b}}$ & 0 \\
\hline Argulussp. & 0 & 0 & 0 & 0 & 0 & 0 & 0 & 0 & 0 & 0 & 0 & 0 \\
\hline Lerneasp. & 0 & 0 & 0 & 0 & 0 & 0 & 0 & 0 & 0 & $6.66^{\mathrm{a}}$ & $6.66^{\mathrm{a}}$ & 0 \\
\hline Chilodonellasp. & 0 & 0 & 0 & 0 & 0 & 0 & $\begin{array}{l}3.3 \\
3^{\mathrm{a}}\end{array}$ & 0 & 0 & 0 & 0 & $3.33^{\mathrm{a}}$ \\
\hline Ergasilus sp. & 0 & 0 & 0 & 0 & 0 & 0 & 0 & 0 & 0 & 0 & 0 & 0 \\
\hline D.Stages & 0 & 0 & 0 & $1.66^{\mathrm{a}}$ & 0 & 0 & 0 & & 0 & 0 & 0 & 0 \\
\hline $\begin{array}{l}\text { Ichthyophthi } \\
\text { rius } \\
\text { multifilis }\end{array}$ & 0 & 0 & 0 & 0 & 0 & 0 & 0 & 0 & $6.66^{\mathrm{a}}$ & 0 & 0 & 0 \\
\hline
\end{tabular}

PFI=Parasitic Frequency Index $(\%) . a=$ rare $(0.1-9.9 \%) ; b=$ occasional $(10-29.9 \%) ; c=$ common $(30-69.9 \%) ; d=a b u n d a n t(70-1)$ 
Table.7 Prevalence (PFI, \%) of parasites in Cirrhinus mrigala in different seasons from April 2014 to March2015

\begin{tabular}{|c|c|c|c|c|c|c|c|c|c|c|c|c|c|}
\hline $\begin{array}{l}\text { Cirrhinus } \\
\text { mrigala }\end{array}$ & & $M y x$ & olussp. & $\begin{array}{l}\text { Theld } \\
\text { p. }\end{array}$ & melluss & Tric & dinasp. & Dacty & yrussp & $A r$ & us & & ages \\
\hline Period & 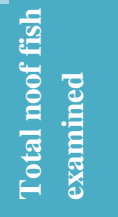 & $\begin{array}{l}\text { No. } \\
\text { ofinfec } \\
\text { ted } \\
\text { fish }\end{array}$ & $\underbrace{\frac{9}{2}}_{\frac{d}{2}}$ & $\begin{array}{l}\text { No. } \\
\text { ofinfec } \\
\text { ted } \\
\text { fish }\end{array}$ & $\frac{2}{2}$ & $\begin{array}{l}\text { No. } \\
\text { ofinfec } \\
\text { ted } \\
\text { fish }\end{array}$ & $\frac{8}{2}$ & $\begin{array}{l}\text { No. } \\
\text { ofinfec } \\
\text { ted } \\
\text { fish }\end{array}$ & $\frac{8}{\frac{2}{2}}$ & $\begin{array}{l}\text { No. } \\
\text { ofinfec } \\
\text { ted } \\
\text { fish }\end{array}$ & $\frac{\partial}{d}$ & $\begin{array}{l}\text { No. } \\
\text { ofinfec } \\
\text { ted } \\
\text { fish }\end{array}$ & $\frac{\sqrt{2}}{\frac{1}{2}}$ \\
\hline $\begin{array}{c}\text { Summer (April- } \\
\text { June) }\end{array}$ & 180 & 35 & $19.4^{b}$ & 20 & $11.11^{b}$ & 5 & $2.77^{a}$ & 16 & $8.88^{b}$ & 0 & 0 & 0 & 0 \\
\hline $\begin{array}{c}\text { Rainyseason } \\
\text { (July- } \\
\text { September)or } \\
\text { Monsoon }\end{array}$ & 180 & 36 & $21.25^{b}$ & 25 & $13.88^{b}$ & 10 & $5.55^{\mathrm{a}}$ & 18 & $10^{b}$ & 0 & 0 & 2 & $1.11^{a}$ \\
\hline $\begin{array}{c}\text { Winter } \\
\text { (October- } \\
\text { January) }\end{array}$ & 240 & 51 & $21.25^{b}$ & 40 & $16.66^{b}$ & 12 & $5^{a}$ & 20 & $8.33^{b}$ & 0 & 0 & 0 & 0 \\
\hline $\begin{array}{c}\text { Spring } \\
\text { (February- } \\
\text { March) }\end{array}$ & 120 & 20 & $16.66^{b}$ & 18 & $15^{b}$ & 5 & $4.16^{a}$ & 10 & $8.32^{a}$ & 6 & $5^{a}$ & 0 & 0 \\
\hline
\end{tabular}

PFI=Parasitic Frequency Index $(\%) . a=$ rare $(0.1-9.9 \%) ; b=$ occasional $(10-29.9 \%)$; $=$ common $(30-69.9 \%) ; d=a b u n d a n t(70-100 \%)$. 
Fig.2Prevalance(PFI\%)ofdifferntparasitesinCatlacatlafrom April2014 tomarch2015.

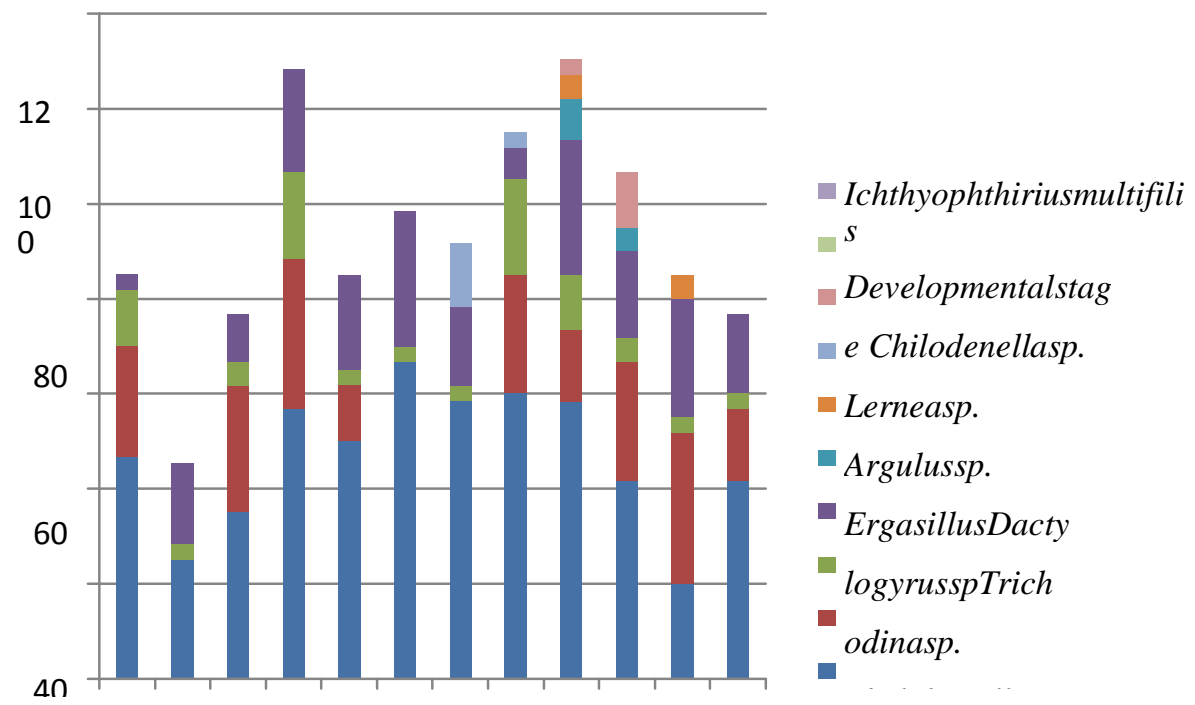

Fig.3Prevalance(PFI\%)ofdifferentparasitesLabeorohitafrom April 2014 tomrch2015.

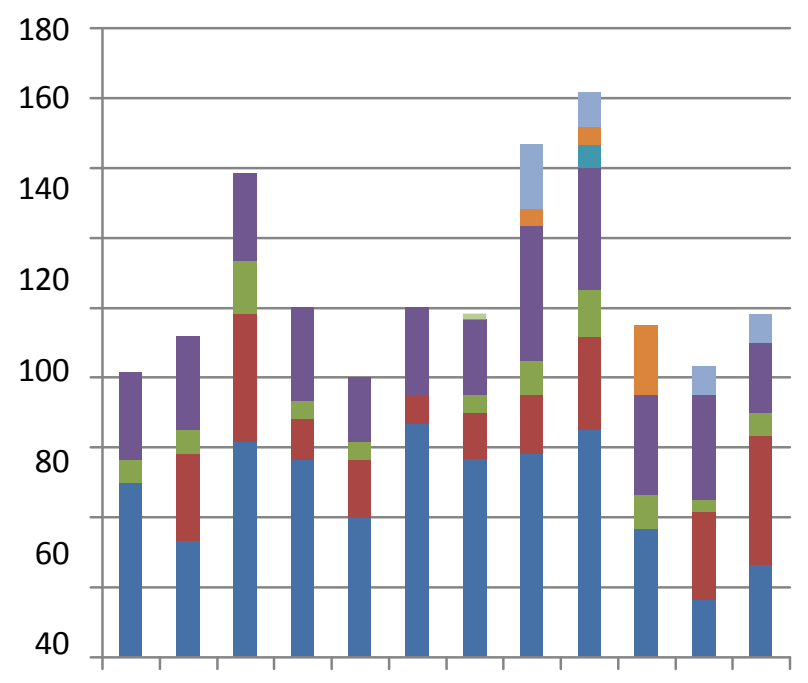

- Ichthyophthirius multifilis

Developmentalstage

Chilodenellasp.

- Lerneasp.

Argulussp.

- ErgasillusDactyl

- ogyrusspTrichod

- inasp.

- Thelohanellussp

Myxobolus sp. 
Fig.4Prevalance(PFI\%)ofdifferntparasitesinCirrhinusmrigalafromApril2014 toMarch2015.

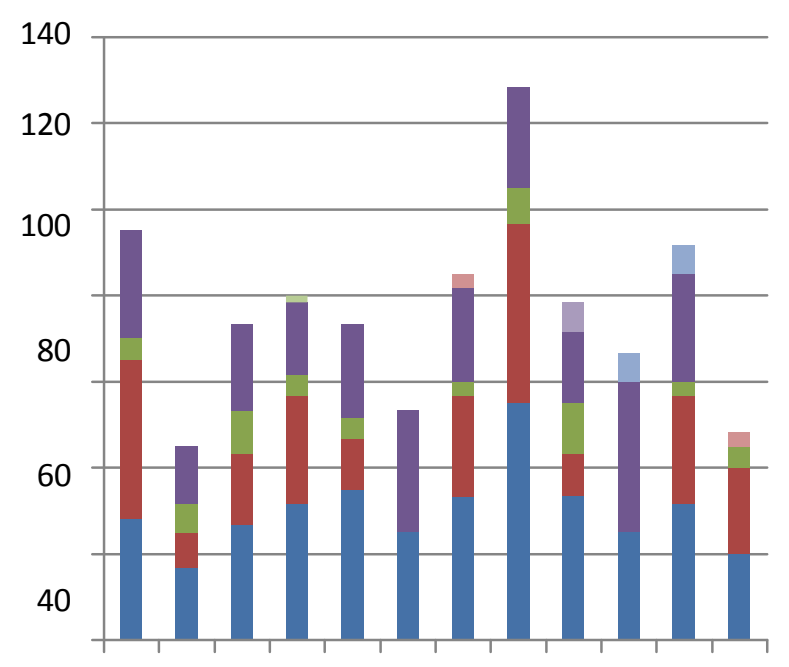

Ichthyophthiriusmultifilis

Developmentalstage

Chilodenellasp.

Lerneasp.

Argulussp.

ErgasillusDactyl

ogyrus spTricho

dinasp.

- Thelohanellussp

Myxobolus sp.

Fig. 5 Prevalance of $\mathrm{PFI} \%$ in Rohu (Labeo rohita) in different seasons from April 2014 to March 2015
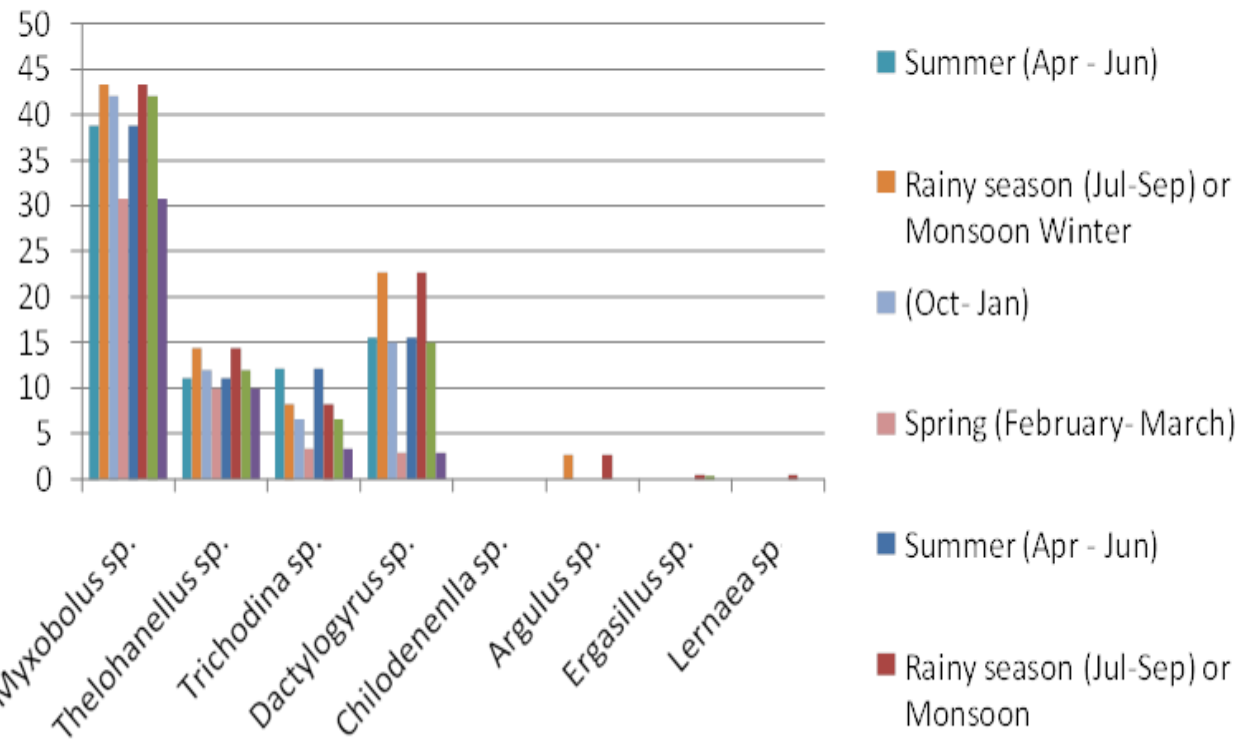
Fig.6PrevalanceofPFI\%inCatla(Catlacatla) indifferent seasonsfrom April2014toMarch2015

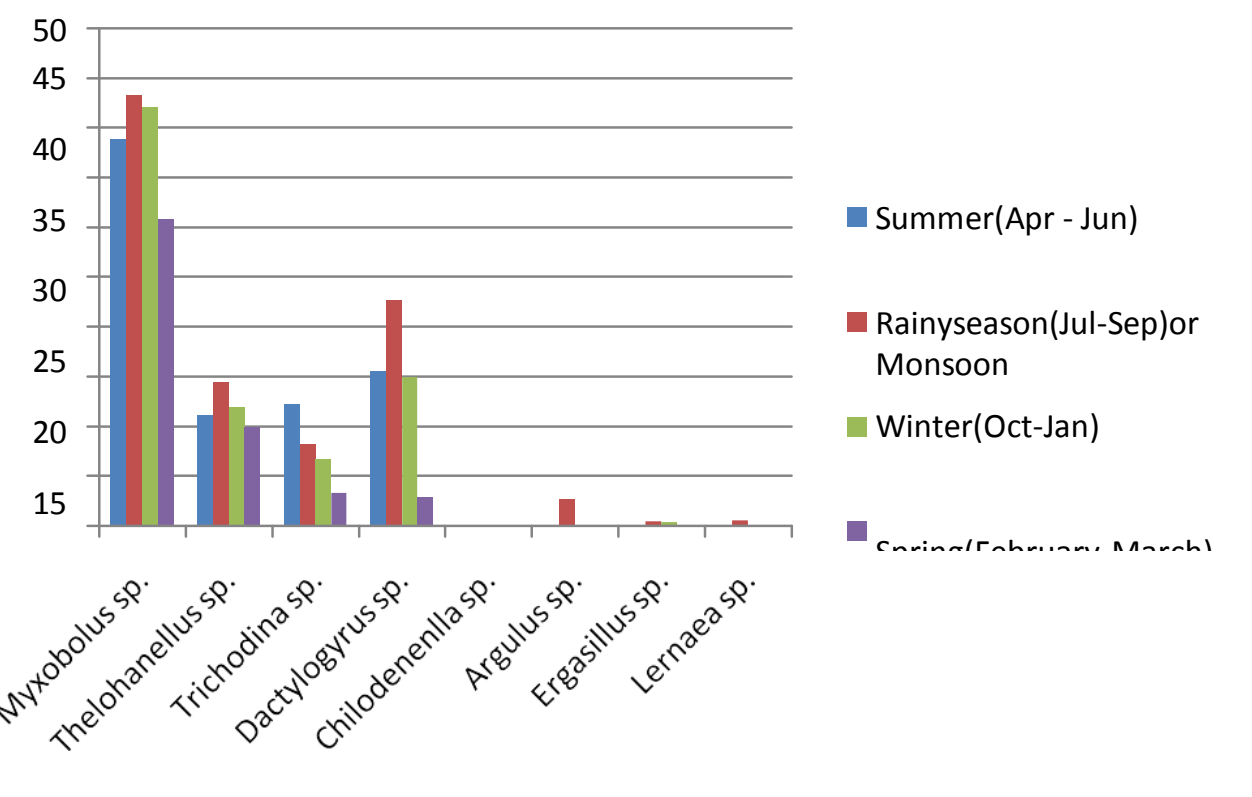

Fig7.Prevalanceof PFI\% inMrigal(C.mrigala)indifferentseasons from

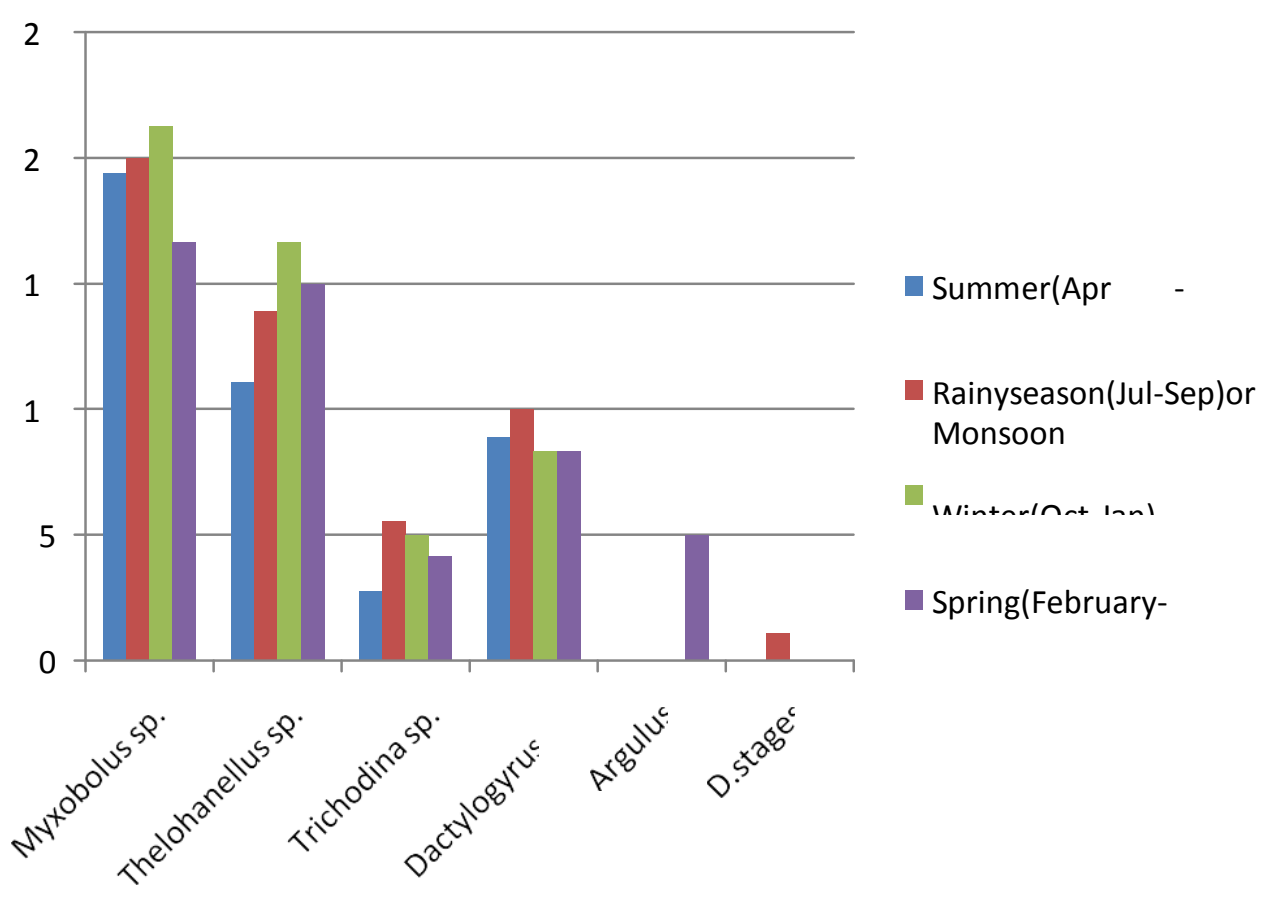


Fig.1 A- Normal and healthy Catlacatla; B- Cyst of Thelohanellus sp. infestation in gills of Catlacatla;C- High infestation of cyst of Thelohanellus sp. in gillsof Catlacatla; DTrichodinasp. withciliapresentinthegillsofLabeorohita(Wet mount,40x); E- Dactylgyrous sp. with distinct marginal hooks present in the gills ofCatla catla (Wetmount,100x); F- Heavy infestation of Thelohanellus sp. present in the gills of Catlacatla (Wet mount,20x); G- Argulus sp. present in the gills of Labeo rohita (Wet mount,40x); H- Myxobolus sp. present in the gills of Catla catla

(Giemsa,100x); I- Myxobolus sp. present on the gills of Cirrhinus mrigala(Giemsa, 100x)

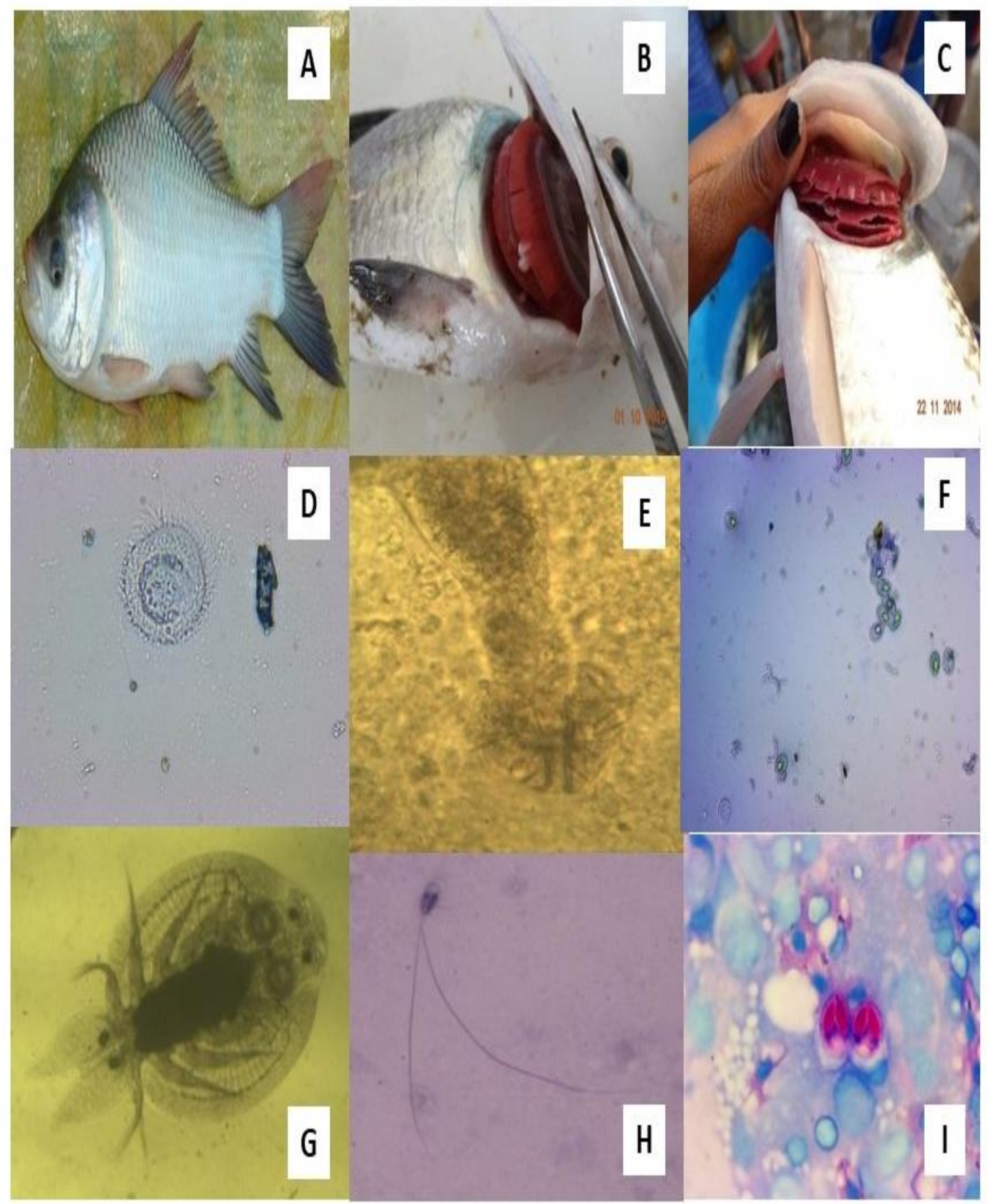


Chilodonella sp. were found only in the month of October (PFI, 3.33\%)and March (PFI, 3.33\%), rest of the months absent. Lernaea $s p$ were found in January(PFI, $6.66 \%$ ) and February (PFI, 6.66\%). Durborow (2003) reported Chilodonella glides over the fish's gill and skin surfaces which supported the present findings. Two species of Chilodonella occur on freshwater fishes, Chilodonella cyprini (Moroff, 1902) occurring on the skin and gills of carp Cyprinus carpio (L) and $C$. hexasticha (Kiernik, 1909) on the skin and gills of tench (Tinca tinca) which also corroborated the present observation. Imai et al., 1985and Ogawa et al., 1985, have been reported Chilodonella hexasticha from the gills of tropical ornamental Symphysodon discus, cichlids (Oreochromis mossambicus, Oreochromis niloticus, Oreochromis aureus), and coldwater cyprinids (Abramis brama, Abramis ballerus, Blicca bjoerkna, Cyprinus carpio). Paperna and Van As (1983) reported that the parasitism with $C$. hexasticha produced severe gill damage in the form of epithelial hyperplasia, which shrouded the fine respirator epithelium and led to the death of the fish.

\section{Occurrence of parasites in different seasons in Cirrhinusmrigala}

The seasonal variation of the parasite occurrence in Cirrhinus mrigala is presented in (Table-7, Fig. 7). Comparatively winter season occurrence was high for Myxobolus sp. than Thelohanellus sp. Akhter et al. (1997), Banu et al. (1993), Chandra et al. (1997) and Hossain et al. (1994) were reported that more incidence of diseases in fish during winter months. Thelohanellus sp. commonly encountered in spring season whereas Myxobolus sp. get reduced and reaches its seasonal low prevalence of PFI $16.66 \%$ in spring.
They were decreased in the prevalence from summer to rainy season (PFI, $19.4 \%$ to $20 \%$ ). ". These results were similar with the works of Bhuiyan et al., 2007, in L. rohita. Thelohanellus sp. were constantly increased in the prevalence from summer and monsoon to winter season (PFI, $11.11 \%$ and $13.88 \%$ to $16.66 \%$ ) and lowest in summer (PFI, $11.11 \%$ ) which stated as occasional. This was probably due to the fact that decrease in water volume during the dry season caused nutritional imbalance resulting in less production of fish foodorganismsinonehandandontheotherhandfa llinwatertemperatureandreduced the immune response in fish and made them more vulnerable to disease vectors. During the study period, the occurrence of Trichodina sp. was highest during rainy season (PFI, 5.55\%) which is stated as "rare". The results were similar with the findings of Balta et al. (2008), who had reported that Trichodina sp. infestations were observed and reached the highest levels during the rainy season. Temperature may be the main factor for the prevalence of Trichodina sp. Dujn (1973) also reported deterioted water quality such as unsuitable water temperature is a reason for Trichodiniasis.

Prevalence of Dactylogyrus sp. highest found in monsoon season (PFI, 10\%) which was stated its condition as occasional and lowest in spring (PFI, 8.32\%), which stated as rare. During the study period Argulus sp. were found rare only in spring season (PFI, 5\%). Rest of the seasons were not found. Developmental stages were found rarely in monsoon season (PFI, 1.11\%) and rest of the seasons these were not found. These results were similar with the findings of Das et al (2015) who had reported that Argulus sp. were found in Spring season (PFI, 2\%) which is stated as rare and not found in the rest of the seasons. The occurrence of developmental stages of eggs/parasites were found only in monsoon season (PFI, 1.11\%), which were 
rare and not found in rest of the seasons. This is similar to the work of Das et al (2015) who had reported that the developmental stages were found rarely in Monsoon season (PFI, $5 \%)$.

\section{Acknowledgement}

I would like to give special thanks to Dr. Gadadhar Dash, my major supervisor, Head and T. J. Abraham, Department of Aquatic Animal Health, for their helpful suggestions for final preparation of this manuscript and also special thanks to ICAR, for financial support during the study.

\section{References}

Ahmed, A., Ali, S. M. K and Samad, A. 1991. Probable cause of fish ulcer in Bangladesh, Nutrition news, 14 (1): 3

Akhter, M., Silva J and Khatun, A. 1997. Helminth Parasites of Anabas testudineus (Bloch) in Bangladesh. Bangladesh Journal of Zoology.,25,135-138.

Anderson, D.P. 1974. Fish immunology. In: Diseases of fishes Stanisias. F. Sneiszko. F. and Axelrod edn., H. R. F. H. publication Inc. New Jersey 07753USA.

Angka, S. L., Promono, S. U., Pasaribu, F. H and Alifuddin, M. 1982. Isolasidan identificasi sasad renik peneyb abepidemi Peniyakid bersak mera pada ikandilara Berat. Bull. Perikanan, 1, 1-14.

Aydogdu, A., andAltunel, F. N. 2002. Helminth parasites (Platyhelminthes) of common carp (Cyprinus carpio) in Iznik Lake. Bulletin of Europian Association. Fish Pathology, 22(5), 343-348.

Ayyappan, S. 2007. Growth through inland aquaculture. Paper presented in the $8^{\text {th }}$ Agricultural Science Congress, Tamilnadu Agriculture University, Coimbatore, India. 15- 7 February, (2007), pp. 1-19.

Banu, A.N.H., Khan and Thulin, M.H. 2004. Waterquality, stocking density and parasites of freshwater fish in four selected areas of Bangladesh. Pakistan Journal of Biological Sciences,7 (3): 436440.

Banu, A.N.H., Hossain, M. A. and Khan, M.H. 1993. Investigation on the occurrence of parasites in carps, catfish and tilapia. Progress of Agriculture, 4, 11-16.

Basu, S. and Haldar D.P. 2003. A v aculates v e study on the prevalence of myxosporeans (Myxozoa: Bivalvulida) in pure and hybrid carps of West Bengal. Ecology Environment and Conservation, 9(2): 147-159.

Bauer, O.N., Musselius, V.A. and Strelkov, Yu. A. 1969. Diseases of Pond Fishes. Publisher-Kolos\|Moskva. In: English:Israel Program for Scientific Translations, Jerusalem.

Bhuiyan, A.S., Sarmin Akther and Golam Mohammad Musa. 2007. Occurrenceof parasites in Labeo rohita (Hamilton) from Rajshahi, University journal zoology Rajshahi University. Vol. 26: pp.31-34

Chandra, K.J., Islam, K. Z. and Wootten, R. 1997. Some aspects of association and development of Lytocestus indicus moghe in catfish, Clarias batrachus. Bangladesh Journal Fish Resources. 1, 31-38.

Das, M.K. and Das, R.K. 1995. Fish Diseases in India-A Review. Environmental Ecology, 13 (3):533-541.

Das, M. K., Halder D. P. and Mondal, S. K. 1989. Macro ecological studies on protozoan disease of carps in tropical intensive fish culture ponds in India. Environmental Ecology, 7(1):1-9.

Das, M.K. 2005. Application of the health Assessment Index (HAI) for rapid evaluation fish health, Journal of Inland Fishery Society of India,37(2): 87-92.

Derwa, H.I.M.1995. Some studies on gill affections of some freshwater fishesll. M. Sc. Thesis, Faculty of Veterinary Medicine, Suez Canal University.

Dujin, C.V.F. 1973. Diseases of Fishes. 3rd edn., I, Life Books, London.pp-110.

Durborow, Robert, M. 2003. Protozoan parasites in southern regional aquaculture 
centre October (2003), publication No.4701.

El-Shahat, R.A. 2004. "Studies on ectoparasites of freshwater fish". Master Thesis submitted to Fac. Of Vet. Med., Zagazig University.

Farhaduzzaman, A.M., Manjurul Alam, M. and Mosharrof Hossain, Afzal Hussain, M. Md.Habibur, Rahman, 2010. Prevalence of Parasites in the Indian Major Carp, Labeo rohita (Hamilton) in Rajshahi, Bangladesh, University of journal of zoology. Rajshahi. Univ. (28): 65-68.

Ghosh, A.K., Dutta, N.C. and Laha, G.C. 1987. Observations on dactylogyrid trematodes of Catla catla from Hooghly, West Bengal. Journal of Inland Fishery Society, India, 19(2):53-60.

Gopalkrisnan, V. 1961. Observation on a new epidemical eye disease affecting the Indian Carp Catla catla (HamiltonBuchanan). Indian Journal of Fisheries, 8: 222-232.

Hines, R. S. and Spira, D. T. 1974. Ichthyophthiriasis in the mirror carp Cyprinus carpio (L). 111. Pathology of Journal of Fish Biology, 6:189-196.

Hoole, D., Bucke, D., Burgess, P. and Wellby, I. 2001. Infectious diseases-parasites.

Diseases of carp and other cyprinid fishes. Fishing News Books, UK., pp.63-122.

Hossain, M. A., Banu, A. N. H and Khan, M. A. 1994a. Prevalence of ectoparasites in carp nursery of Greater Mymensingh. Progress. Agriculture, 5(2): 39-44.

Imai, S., Hatai K. and Ogawa, M. G. 1985. Chilodonella hexasticha (Kiernik, 1909)found from the Institute of Food and Agricultural Sciences (IFAS) University of Florida. pp.125.

Kabata, Z. 1985. Parasites and disease of fish cultured in the tropics. Taylore and Francis Ltd., London. pp.318.

Kaur, H., Rajni Attri and Ranjeet singh. 2012. Incidence Of Gill Myxoboliosis In Catla Catla (Ham Ilton-Buchanan) In Harike Wetland Of Punjab, Trends In Parasitology Research, Vol.1 no.2,pp.912.
Kim, K. H., Ahn, K. J. and Kim, C. S. 2001. Seasonal abundances of Prosomicrocotyla gotoi (Monogenea) and Opecoelus sphaericus (Digenea) from greenlings Hexagrammos otakii in a southern coastal area in Korea. Aquaculture, 192: 147- 153.

Kollmann, A. 1972. Dactylogyrus vastator Nybelin (1924) (Trematoda: Monogenoidea) als Krankheitserreger auf den kiemen des karpfens (Cyprinus carpio L.) 3. Teil. Zeit. Wiss. Zool., $185: 1-54$

Landsberg, J.H. 1989. Parasites and associated diseases of fish in warm water culture with special emphasis on intensification. In Shilo, $M$ and Sarig, S. (ed) Fish Culture in Warm water Systems: Problem and Trends. CRC Press Inc, Boca Raton, Flo., pp, 195-252.

Leong, T.S. 1992. Diseases of brackish water and marine fish cultured in some Asian countries. In: Diseases in Asian Aquaculture. Shariff M., Subashinghe R.P. and Arthur T.R. (.edn). Asian Fisheries Society, Philippines.

Lumanlan, S.C., Albaladejo. J.D., BondadReartaso. M.G. andArthur, J.R. 1992. Fresh- water fishes imported into the Philippines: In: Diseases in Asian Aquaculture, (eds.). Shariff, M. Subashinghe R. P. and Arthur, J.R. Asian Fisheries Society, Philippines

Majumder, D. 2011. Study on Parasites of Exotic Carps In South 24 Parganas of West Bengal, M.F.Sc. thesis, West Bengal University of Animal and Fishery Sciences, Kolkata, 143p.

Mikheev, V. N., Pasternak, A. F., Valtonen, E. $\mathrm{T}$ and Lankinen, Y. 2001.Spatial distribution and hatching of overwintered eggs of a fish ectoparasite, Arguluscoregoni (Crustacea: Branchiura). Diseases of Aquatic Organisms, 46(2): 123-128.

Mohan, C.V., Ramaiah, $\mathrm{N}$ and Shanbhogue, S.L. (1986). Effects of some therapeutics on fish ectoparasites. Environmental and Ecology, 4(1): 98-100. 
Mo, T. A. 1992. Seasonal variations in the prevalence and infestation intensity of Gyrodactylus Malmberg. 1957 (Monogenea: Gyrodactylidae) on Atlantic salmon parr, Salmo salar L. in the River Batnfjordselva, Norway. Journal of FishBiology,41: 691-707.

Moroff, T.H. 1902. Chilodon cyprinid nov. Sp. Zoologischer Anzeiger. 26: 5-8. Mrigala (Ham.) with a note on spore load. Mysore Journal of Agricultural. Sciences, 14: 385-387.

Nandi, N. C. and Das, S. R. 1991. Argulosis causing Juveniles Mortality in some fishes in Kakdwip, West Bengal. Indian journal of Fisheries, 38(2): 132-133.

Narasimhamurti C.C. and Kalavati, C. 1984. Seasonal variation of themyxosporidian Hennegvya walairensis parasitic in the gills of the freshwater fish, Channapunctatus Bl. Arch. Protistenk, 131: 351-356.

Ogawa, K. 1988. Occurrence of Bivagina tai (Monogenea: Micrtocotylidae) on the gills of cultured red sea bream Pagrus major. Nippon Suisan Gakkaishi. 54:6570

Ogawa, M., Hatai, K. and Kubota, S.S. 1985. On the so-called gill disease known in the discus, Symphysodon discus, a tropical fish. Bull. Nippon Veterinary Zootechnical College, 34:100-104.

Osman, H.A.M. 2001. - Studies on parasitic gill affections in some cultured freshwater fishesll. Master thesis submitted to the Faculty of Veterinary Medicine, Suez Canal University.

Paperna, I. and Van As J.G. 1983. Epizootiology and pathology of Chilodonella hexasticha (Kiernik, 1909) (Protozoa, Ciliata) infections in cultured cichlid fishes. Journal of Fish Biology, 23:441-450.

Paperna, I. 1963a. Some observations on the biology and ecology of Dactylogyrus vastator in Israel. Bamidgeh, 15:8-29.

Passion, D.R.M. 1984. Biochemical indicator in fish. An overview in contaminants effects in Fisheries, Cairns. V.W, Hodson. V.P. and Nriagu J.O. edn., John Willyand Sons, USA.

Plumb, J.A., Grizzle and Figueiredo J.M. 1988. Necrosis and bacterial infection in channel catfish Ictalarus punctatus following hypaxia. Journal of Wildlife Dieases, 12: 247-253.

Polanski, Yu. I. 1961. Zoogeography of parasites of the USSSR marine fishes. In:Parasitology of fishes (English translation) (Eds. Dogiel, V.a., Petrushevskii,G.K. and Polyanski, Yu. I.) Edinburgh and London: Oliver and Boyd, pp.230-246.

Radheyshyam., Sharma, B. K., Sarkar, S. K, and Chattopadhyay. 1993. Environmental stress associated with disease out-breaks in fish in an undrainable weed infested pond. Environmental and Ecology, 11(1):118-122.

Rahman, M. R. and Jahan, M.S. 2002. Consequences of Larval Helminth Infecting Freshwater Gastropods. Bangladesh Journal of Zoology. 30(2): 101-114.

Ray, P. 1993. Aquaculture in Sunderban Delta, it's perspective- An Assessment, Published by international Books and Periodical Supply Service., pp: 1-197.

Samir, 2007. A Pathoanatomical and Limnological study of Argulosis in Indian Major Carps in the Freshwater Bheries of West Bengal, M.F.Sc. thesis, WestBengal University of Animal and Fishery Sciences, Kolkata, 91p.

Schaperclaus, W. 1954. Handbuch der Fischkrankheiten. Akademie Verlag, Berlin.

Seenappa, D. and Manohar, L. 1980. Intensity of Myxobolus vanivilasae (Myxospondia) parasite in Cirrhinus mrigala (Ham.) with a note on spore load. Mysore Journal of. Agricultural Sciences, 14: 385-387.

Shafir, A. and Van As, J. G. 1986. Lying, development and hatching of eggs of the fish ectoparasite Argulus Japonicus (Crustacea: Branchiura). Journal of Zoology, 210: 401-414. 
Sharif, M. and Vijiarungam, A. F. 1986. The occurrence of parasites at the fish breeding station in peninsular Malaysia and their control. Proc. Intercont. Dev. Managem. Trop. Living Aquat. Resources, Serdang, Malaysia. Pp. 68-73.

Shella, F., Sivakumar, A.A. and Chandran, R. 2002. Infestation and prevalence of copepod parasite, Argulus indicus on some freshwater fishes. Nature of Environmental Pollution Technology, 1(2): 201-206.

Shimura, S. 1983a. Seasonal occurrence, sex ratio and site preference of Argulus coregoni Thorell (Crusteacea: Branchiura) parasitic on cultured freshwater salmonids in Japan. Parasitology, 86: 537-552.

Shimura, S. 1983b. SEM observation on the mouth tube and preoralsting of Argulus coregoni. Thorell and Argulus xxxaponicas Thiele (Crustacea: Branchiura). Fish Pathology, Tokyo, 18: 151-156.

Shresta, G.B. 1990. Status of Epizootic Ulcerative Diseases Syndrome (EUDS)in Nepal. In regional research program on relationship between EUS in fish and envi ronment. 13-16 August, 1990. NACA. Bangkok, Nepal Reportpp.35-38.

Singhal, R. N., Jeet, S., and Davies, R. W. 1986. The relationships between changes in selected physicochemical properties of water and the occurrence of fish parasites in Haryana, India. 27(1):1-9.

Snieszko, S.F. 1974. The effect of environmental stress on out break of infectious diseases of fishes, Journal of Fish Biology, 6: 197-208.

Song, Y.L., Chen S.W., Kou G.H., Lin C. L. and Ying Y.Y. 1980. Evaluation of Hivax vibrio, Angullarum baclevia in the vaccination of Milkfish (Chanoschanos) fingerlings. Fish Diseases, III, 101-108.

Srivastava, C. B. 1980. Estimation of helminthic infections. Proc. Workshop Tech. Parasitolgical and Zoological Survey of India. pp.29-31.

Subasinghe, R. P. 1992. Hatchery diseases of freshwater fish in Sri Lanka. In, Diseases in Asian Aquaculture, edited by $\mathrm{M}$. Shariff, R.P. Subasinghe and J.R. Arthur, Asian Fisheries Society, Philippines.

Welch, P. S. 1941. Dissolved oxygen in relation to lake types. Symposium on Hydrobiology Press, 377.

Wisheiwski, W.L. 1958. Characterization of the parasite fauna of an Eutrophic lake. Actoparasitologica, 6: 1-64.

Wooten, R. 1974. The spatial distribution of Dactylogyrus amphibothrium on the gills of ruffle Gymnocephalus cernua and its relation to the relative amounts of water passing over the parts of the gills. Journal of Helminthology, 48: 167-174.

\section{How to cite this article:}

Vijaysundardeva, G., Gadadhar Dash, Kurva Raghu Ramudu, T.J. Abraham and Shyam, K.U. 2018. Prevalence of Parasitic Diseases of Indian Major Carps in Selected Districts of West Bengal, India. Int.J.Curr.Microbiol.App.Sci. 7(06): 2784-2805. doi: https://doi.org/10.20546/ijcmas.2018.706.327 